\title{
Inovation Of Teaching Media Through E-Book for Study Middle and Estern Indonesian Food Processing
}

\author{
Sulistiawikarsih $^{1}$, Mastarina Barus ${ }^{2}$, Siti Sutanti ${ }^{3}$, Mawadda Azizah Sari Waruwu ${ }^{4}$ \\ \{1 ${ }^{\text {sulistiawikarsih8@gmail.com, }}{ }^{4}$ mawaddaasw@gmail.com \} \\ ${ }^{1}$ Department of Family Walfare Education, Faculty of Engineering, Medan State University, Medan, \\ Indonesia
}

\begin{abstract}
This study aims to assist teaching staff in developing learning media, especially learning innovations in improving e-book teaching materials for Middle and Estern Indonesian Food Processing as learning media for students and to improve students' knowledge and competence in processing and serving Indonesian food seen from the results of student culinary testing. in Middle and Estern Indonesian Food Processing courses. This study uses the Research and Development (R \& D) method. Learning media produced in the form of e-book media. Data obtained through questionnaire techniques, assessment sheets from media experts and material experts. The subjects of this study were the third semester students of Tata Boga Unimed which amounted to 30 undergraduate students. Based on the results of data analysis and discussion, it can be concluded that e-book learning media can help teaching staff and students in developing learning media, especially the development of students' knowledge. The use of e-book media has a positive effect on student knowledge, with the average value of the experimental class higher, namely 43 and the control class with an average of 39.14 .
\end{abstract}

Keywords: e-book, middle indonesian food, estern indonesian food, food processing, teaching media

\section{Introduction}

Education is a complex process along with human development. Through education various aspects of life are developed through the process of learning and learning. Various problems in the learning process need to be harmonized and so that learning conditions are created in accordance with the objectives to be achieved and can be obtained as optimally as possible. To complete the learning and learning component in school, the task of a teacher should be to use media or tools that are able to stimulate learning effectively and efficiently.

The presence of media means quite important. The obscurity of the material delivered can be helped by presenting media as an intermediary. The complexity of the material to be delivered to students can be simplified with the help of the media. Information technology and computers today have developed so rapidly. In the field of education, the presence of computers provides its own color by using it in learning activities and proven to have many advantages. Especially in learning, the ability of computers that are able to integrate many media, is very helpful to understand the material and make students happy in learning. This requires the teacher to always develop the skills to create learning media, so that the material delivered to students can be easily accepted, interesting, motivate students and in accordance 
The above problems are generally faced by many with the desired goals. To help students overcome difficulties in mastering the material.

The above problems are generally faced by many technological and vocational education institutions because technology as an object being studied is a dynamic (always developing) field and some have global coverage. The Unimed Culinary Education Program also faces disparity issues as above. Some of the courses taught are included in the technology field and have a global scope, including Indonesian Middle Eastern Food Processing. In this course students are required to be able to process and serve Indonesian food consisting of staple foods, side dishes, vegetables, special drinks and delicious tasting. (Syllabus for Middle Eastern Indonesian Food Processing Courses). The aim of this course is that students after following it can understand the Eastern and Central Indonesian culinary, skilled in processing and serving Indonesian dishes. The curriculum of this course is arranged in 3 practice credits, where all the subjects given in the form of face-to-face for one semester are practical activities. Yet to fulfill the demands of the course in understanding Indonesian Middle Eastern food culinary is not enough to be obtained only through practical activities. Concretely this gap problem arises when several graduates are accepted to work in the restaurant industry or hotels that serve Middle Eastern Indonesian cuisine. As according to the acknowledgment of some alumni who currently work in international standard restaurants and hotels, it turns out that their academic abilities and skills are still not enough to carry out the job description. There are still many new things, especially concerning some techniques, recipes, and culinary that they have not yet obtained in college so that they still have to enrich their knowledge by digging from sources outside of academics, for example by taking courses, reading books and articles in the mass media, as well as the use of the internet.

From this it appears that even though graduates have been equipped with the knowledge and skills of the campus, in the end they are still required to study independently after entering the workforce. Regarding the excavation of knowledge outside of academics, it can actually be done since graduates still attend lectures. There are several things that cause this to not be done by students. First, lack of motivation and awareness from educators, so students do not see the importance of extracting knowledge and information outside of academics. Second, both educators and students are less able to see the benefits or effects of learning outside of academics for enrichment of lecture material. Excavation of knowledge outside of academics can be done by using the internet. The widespread use of the internet for educational purposes, especially in developed countries, is a fact that shows that with this media it is possible to hold a more effective learning process. This happens because with the characteristics and characteristics of the internet that are quite typical, it is hoped that it can be used as a source of learning as other sources have been used previously such as radio, television, interactive CDROM and others. The results of student lab work are determined by the value of preparation, process, and final results. In the final result the value is determined by the taste of the food, the accuracy of the recipe and presentation which consists of elements of appearance, addition of garnish, accuracy of portions, and accuracy of serving utensils. But all this time in practicum in the Middle Eastern Indonesian Food Processing course, the presentation of the results of student practices tended to be as they were and waited for examples from the lecturers. This shows that students' insights and creativity in terms of variations in presentation are still lacking. The internet can used by students in learning Middle Eastern Indonesian Food Processing courses to add insight and stimulate the emergence of ideas in the presentation of practical results. Images of cuisine in a culinary site can be adopted by students to enhance creativity in presenting the results of their practice. So that when students often see and utilize the media, the wider the insight and acquisition of ideas in the presentation that can be applied 
in practicum. This is supported by the results of a study conducted by [6]that the application of internet-based peer tutoring learning models proved effective in increasing student learning activities. Based on the description above, it can be said that in an effort to improve the quality of learning to improve student achievement, it is necessary to explore knowledge and insights outside the campus. For this reason, it is necessary to conduct research that will provide answers to whether learning outside of academics has an influence on enrichment of lecture material. The learning methods outside the academic that will be examined here are internet learning resources in the form of e-books.

In this case, it is obligatory for students to access electronic learning resources. Even though it is optional, students who use it will certainly have additional knowledge or insight, complementary (complement) that is if the source of electronic learning is programmed to complement the learning resources that students receive in the classroom [1]. As a complement means the source of electronic learning is programmed to be a source of reinforcement (enrichment) or remedial for students following conventional learning activities, and substitution (substitute) of this function in developed countries has been applied to several universities, where learning methods with internet learning resources for example among them in the form of e-books to be one alternative substitute for lecture activity models to students with the aim that students can flexibly manage their lecture activities in accordance with the time and other activities of everyday students.

\section{Methodology}

\subsection{Types Of Research}

This research uses research and development methods. Research and development ( R \& D) can be defined as research methods that are intentional, systematic, aim/directed to find, formulate, improve, develop, produce, test the effectiveness of products, models, methods / strategies / methods, services, procedures that are superior, new, effective, efficient, productive, and meaningful [2]. In order to produce e-book media products as learning media that are able to help students at the stage of development of knowledge in the field of expertise, the development model that will be used in this study is the model of education research and development (Educational Research \& Development). According to Borg \& Gall [3] that research and development consists of 10 stages, but in [6] the procedure of development research according to Borg \& Gall can be done more simply, which is only doing 5 main steps, namely: (1) Analyze the product to be developed, (2) Develop the initial product, (3) Validate and revise, (4) Small-scale field trials and product revisions, (5) Largescale field trials and final products.

\subsection{Trial Design}

Product testing is a development stage carried out in two stages, namely trial 1 (limited trial) and trial 2 (field trial). Limited trials using the design of one shot Case Study because the assessment only uses the final value of learning outcomes (posttest) without using a pretest[4]. The field trial used a quasi-experimental method with a pretest and posttest control group design. Class A control class and class B experimental class. 


\subsection{Method of collecting data}

The data obtained from this study is primary data. This data is data relating to validation and responses from media and material experts, and lecturers about e-book learning media developed by researchers. In addition, the implementation data from e-book media in the learning process and e-book effectiveness data in increasing knowledge after participating in learning activities.

Data collection techniques in this development research are hypothetical models of ebook learning media and observation guidelines. The hypothetical model is a model design that will be tested for its feasibility in the field. While the observation guideline is a tool used for reference observations. The observation guide in this study uses a rating scale. Observation can be done in a participatory or non-participatory manner [6]. In this study, researchers used nonparticipatory observation where researchers did not participate in activities, researchers only had the role of observing activities that took place in the field, not participating in activities

\subsection{Data analysis technique}

To find out the quality of learning media that has been developed both from the material aspect and from the aspect of the media, the data that is still in the form of scores are converted into qualitative data (data intervals) with a scale of five.

The data obtained were analyzed using qualitative descriptive statistics. This analysis is intended to describe the characteristics of the data in each variable. With this, it is expected to facilitate the understanding of data for the subsequent analysis process. The results of data analysis are used as a basis for revising the developed media products. Test the hypothesis using SPSS (Statistical Package for Social Scores) 16.0 for Windows, a statistical test package for social science. The t-test is used to determine the significance of the influence of the independent variable, e-book (X) learning media on the Central and Eastern Indonesian Food Processing Courses (Y) so that it can be known whether existing allegations can be accepted or rejected.

\section{Result and Discussion}

\subsection{Preliminary Research}

Needs analysis is carried out by conducting interviews with Lecturer Lecturers, the results of interviews related to learning media that have been carried out and desired by educators, show that the relevant lecturers often have difficulty in delivering material, especially in delivering and introducing material. Difficulties experienced are related to the response of students who are less motivated in listening to the material given by lecturers, because of the lack of specific learning media in prescribing and manuals. For this reason, learning is often done by teachers by lecturing, and analyzing recipes according to the topic of discussion at that time. After conducting a field analysis at the research site about the needs of lecturers while teaching, researchers can draw a conclusion that in the learning process the lecturers have difficulties, due to lack of media and guidebooks, especially material about processing central and eastern Indonesian food. As a result of limited learning media used, especially in 
terms of reference books so students only imagine what is explained by the lecturer, and students tend to be bored, sleepy and crowded with their friends.

\subsection{Preparation of Product Prototypes}

After reviewing the results of the educator's needs analysis, the next step is to develop a prototype product for learning media development. The procedure for developing the big book learning media is as follows: determining the material adapted to the learning event unit $(S A P)$ or semester learning plan (RPS), implementing the development, compiling an e-book learning media for the formation of teaching materials, review and trial of products consists of reviews of media experts and material, revisions, and small and large scale trials, and the final stage is the final e-book learning media for teaching materials.

\subsection{Trial Results of Development Results}

In validating a learning media product that was developed, material experts used were lecturers Dra. Siti Wahidah, M.Sc. The material expert test was carried out through discussions, questionnaires, interviews with the following results, the material expert consisted of 1 lecturer namely Indonesian Food Processing Lecturer. The data collected through questionnaires shows that, from the aspect of material content that the material is in accordance with the determined material indicators, while for the language aspect that the language used still needs improvement, which is adjusted to the enhanced spelling language $(E Y D)$, so that teaching can be accepted easily. Overall, the assessment of material and language aspects reached 122 with the final average of 4.06 which if converted from quantitative to qualitative is included in the good category. In addition to the questionnaire, interviews were also conducted on e-book learning media products, both about the truth of the concept, the depth of the discussion, and the responses and general comments in the framework of improvement or revision before going to the next stage. The results of interviews with material experts that, e-book learning media products need to be added, because if the product is made only one type, the results obtained are less than optimal, and students will quickly get bored if the product used is only one type. In the sub-section of material, there are still non-standard sentences, there are still very long sentences, so it needs to be simplified again. Then in the recipe indicator, there are still some non-standard recipes, so it needs to be replaced with another that matches the latest level of prescription development and daily practice in the laboratory. Conclusion of results from material experts, e-book learning media products are feasible to be tested with revisions. The results are reviewed by researchers, as a basis for product improvement, especially in terms of product appearance and product presentation.

Media expert validation was carried out by $P K K$ lecturers who were also lecturers of the Postgraduate Program namely, Dr. Dina Ampera, M.Sc. Learning media expert evaluation is intended to obtain input about the quality of media display, and aspects of learning. The results of the evaluation of learning media experts are in the form of an assessment score on several aspects that cover the display aspects, and aspects of learning. Assessments carried out by media experts get a score of 146 if averaged get a result of 4.05 and if converted from quantitative to qualitative are included in the good category. In addition to conducting assessments through questionnaires, media experts also provide input on e-book learning media products, namely from the color aspects contained in the media, the combination of colors contained in e-books using contrasting and bright colors to attract students' attention, the use of media products The e-book is further clarified by the steps to use. 
Then in the discussion of the material, it is better if you use the recipe, the recipe used is the standard recipe. While the fonts and letters of writing in the text are more enlarged, using fonts 12-14 in order to facilitate students in understanding the material, the format of writing to be re-trimmed and supported by decoration on each page, then the flow in the chapter is made more systematic. After giving advice on e-book learning media development products, the final stage of the media expert concluded that e-book learning media is feasible to be tested with revisions [5]. The results of reviews from media experts were reviewed by researchers, as a basis for product revi-sions, especially from the aspect of appearance.

Learning media that have been validated by material experts and media experts and have been revised based on records from these experts, then tested on a limited field. Limited field trials using a sample of students in the class group of 6 students. The use of e-book media itself, is used every time in the small class research process [6]. The researcher explained about the use of e-book media to educators, whereas the use of the media students was also involved so that students could understand each chapter of the material provided, besides the purpose of the use of the media, inviting them to get to know the recipes in the media. The results obtained can be seen that, each indicator on the value of the material has a moderate value, only on the indicator in analyzing the recipe has a high value. Overall, the use of e-book media in the preparation of materials reached 3.36 in the high category. The results of this small group trial were reviewed by researchers, as a basis for product revisions for large group trials. In this small group trial, discussions and observations were also carried out, according to the lecturer, the e-books used had a high level, students preferred to access rather than buy or look for reference books.

Extensive trials of e-book learning media were carried out after limited trials. There are two classes that are used in the KB A class and KB class. Before using the learning media ebooks the researchers do the pretest first, namely by making observations before applying ebook learning media. The observations were carried out on the two classes selected, namely class $\mathrm{A}$ as the control class and class as the experimental class. In the assessment using these two classes, the researcher asked for help from one of the class A lecturers as observers. The results obtained at the pretest of the control class were 31.64 in the "good" category. Whereas in the experimental class the average value was 32.28 in the category of "good". After evaluating the pretest in the control and experimental classes, the researcher conducted a posttest in the control class and the experimental class. This assessment was carried out after using e-book learning media for the experimental class and in the control class the storytelling lecturer used a guidebook prepared by the researcher.

The results obtained by researchers in the posttest of the control class were 39.14 with the category "very good", and the experimental class 43 with the category "very good". In addition to assessing the results of the media use test post, also evaluating the results of different test achievement of each character value given, the results of different tests obtained on the material values based on the calculation of independent sample t-test on the student achievement standards can be seen that $F=0.200$ with the significance level of 0.670 is greater than 0.050 . This shows that the actual standard gain variance of student character achievement between the control and experimental classes is the same, namely $-2,777$. In this test the two variances are used (equal varians assumed). The standard t-gain test for the same variance is $-2,777$ with a significant level of 0.032 . Because the value of a significant level is smaller than 0.05 then $\mathrm{H}_{0}$ is rejected. Based on this, it can be concluded that there are significant differences in the achievement of the preparation of student teaching materials between classes using conventional learning media with learning media as a result of development. Different test results for character discipline values, based on calculation results. 
independent sample t-test on the gain standard of student character achievement can be seen that the value of $F=0.725$ with a significance level of 0.419 greater than 0.05 . This shows that the actual standard gain variance of student character achievement between the control class and the experimental class is the same, namely $-4,575$.

In this test the two variances are used (equal varians assumed). $t$ standard gain shows that it has the same variance of -4.575 with a significance level of 0.002 . Because indigo significance level is smaller than $0.05, \mathrm{H}_{0}$ is rejected. Based on this, it can be concluded that there are significant differences in the achievement of the preparation of teaching materials between classes using conventional learning media and learning media as a result of development. And the results of different tests for material values based on the results of the calculation of the independent sample t-test on the gain standard achievement of student characters can be seen that the value of $F=0.157$ with a significance level of 0.712 greater than 0.05. This shows that the actual standard gain variance achievement of student knowledge between the control class and the experiment is the same, namely -0.868 . In this test the two variances are used (equal varians assumed).

The calculation results show that the standard $t$ gain for the same variance is -0.868 with a significance level of 0.434 . Because the significance value is greater than 0.05 then $\mathrm{H}_{1}$ is rejected. Based on these results it can be concluded that there is no significant difference in the achievement of the preparation of teaching materials using conventional learning media with classes that use learning media as a result of development. After calculating the knowledge and inland materials it can be concluded that e-book learning media has a significant influence on the preparation of Central and Eastern Indonesian Food Processing teaching materials for students. This happens because in the learning process students are involved directly in applying in the culinary and laboratory fields when practicing to see the results of competencies at the end of learning. After testing e-book learning media products, researchers gave questionnaires to educators. The assessment conducted by lecturers after using e-book media got very high results, namely 8.57 . This, included in the category of proper use in the learning process, especially in learning to increase student knowledge.

\section{Conclusion}

The development of e-book learning media is carried out through five stages, namely: needs analysis, initial product development, expert validation and revision, small-scale field trials and revisions, and large-scale field trials and final products. In the assessment process carried out by experts, the material experts produced a mean score of 4.06 with good categories, and media experts by obtaining a mean score of 4.05 in the good category. With the conclusion that e-book learning media is feasible to be tested with revisions as recommended. There were differences in scores between the control and experimental classes, the experimental class obtained a mean score of 43 with a very good category, and the average score for the control class was 39.14 with a very good category. From the average acquisition obtained, the experimental class obtained better results than the control class. With this acquisition, it can be concluded that e-book learning media has a significant influence on students as an innovation in developing Central and Eastern Indonesian Food Processing teaching materials for student. 


\section{Suggestion}

For Educators The results of this development can be used as an alternative learning media in the introduction of Central and Eastern Indonesian Food Processing material to students. This product can stimulate the spirit of students to get involved in learning, especially when lecturers explain. For Future Researchers It is hoped that future researchers can conduct research on training with educators in the development of learning media that use interactive media.

\section{References}

[1] A. B. Hakim, "Efektifitas Penggunaan E-Learning Moodle, Google Classroom dan Edmodo," I-STATEMENT Inf. Syst. Technol. Manag., vol. 2, no. 1, 2016.

[2] T.W.A. Putra and Q. Shinta, "Rancang Bangun Aplikasi E-File Sebagai Sarana Pengumpulan Data Dosen," in Science and Engineering National Seminar, 2015, vol. 1, no. 1, pp. 331-344.

[3] W. R. Borg and M. D. Gall, Research Education: an instruction. New York: Longman Tnc, 1983.

[4] Sugiyono, Metode Penelitian Kuantitatif Kualitatif dan $R \&$ D . Bandung: Alfabeta, 2008.

[5] S. Muhammad, "Efektivitas Pembelajaran Media E-Learning Berbasis Web Dan Konvensional Terhadap Tingkat Keberhasilan Belajar Mahasiswa," Fakultas Ekonomi Universitas Bina Darma Palembang, 2014.

[6] Ali, "Studi Pemanfaatan E-Learning Sebagai Media Pembelajaran Guru dan Siswa SMK Di Yogyakarta,” J. Pendidik. Vokasi, vol. VI, no. Februari, 2015. 